\section{Landscape Performance of Ebony Crepe Myrtle Cultivars in Low-input Landscapes in North- central Texas}

\author{
Derald Harp $^{1}$, Kevin Chretien ${ }^{2}$, Mariah Brown $^{3}$, Curtis Jones ${ }^{1}$, \\ and Jose Lopez-Serrano ${ }^{1}$
}

\begin{abstract}
Additional index words. Acanthococcus lagerstroemiae, Altica, crepe myrtle aphid, crepe myrtle bark scale, dark foliage, Erysiphe lagerstroemiae, flea beetle, Lagerstroemia indica, leaf temperature, powdery mildew, Tinocallis kabawaluokalani
\end{abstract}

Summary. The Ebony series of crepe myrtle (Lagerstroemia indica) cultivars includes several (Ebony Embers, Ebony Fire, Ebony Flame, Ebony Glow, and Ebony and Ivory), marketed today under the Black Diamond ${ }^{\circledR}$ brand. These are relatively new crepe myrtle cultivars unique for their dark foliage, but with little information concerning their performance in north-central Texas, especially in low-input landscapes. The study was conducted from 2014 to 2017 at three locations in north-central Texas with three soil types, an acidic fine sandy loam, a neutral $\mathrm{pH}$ silt loam, and an alkaline heavy clay. Although soils and environmental conditions caused variations between sites, overall performance among cultivars was consistent across all study sites, with Centennial Spirit having better landscape performance than any of the Ebony cultivars tested. 'Ebony and Ivory' and 'Ebony Blush' had the overall lowest landscape performance. Ebony cultivars grew more slowly, had fewer blooms, and were more susceptible to powdery mildew than Centennial Spirit. While the trees may perform better in more intensively managed landscapes, the Ebony cultivars did not perform as well as Centennial Spirit in low-input landscapes in north-central Texas.

$\mathrm{C}$ repe myrtle (Lagerstroemia indica) is an important shrub and small tree in Texas landscapes and across the southern United States. In 2014, wholesale sales of

Received for publication 5 Oct. 2020. Accepted for publication 23 Dec. 2020.

Published online 26 January 2021.

${ }^{1}$ College of Agricultural Sciences and Natural Resources, Texas A\&M University-Commerce, P.O. Box 3011, Commerce, TX 75429

${ }^{2}$ Ruibal's Plants of Texas, 161 Haymarket Road, Dallas, TX 75253

${ }^{3}$ El Centro Community College, 801 Main Street, Dallas, TX 75202

We thank J. Berry Nursery. Bentley Burrus and the staff of the Greenville Sports Park, the City of Greenville. and Bob Williams and the staff of the Texas A\&M University-Commerce Twin Oaks Blueberry Farm who helped make this research possible. We also thank the Houston Livestock Show and Rodeo for their financial support.

Mention of a trademark, proprietary product, or vendor does not constitute a guarantee or warranty of the product by the authors, Texas A\&M University-Commerce, El Centro Community College, Dallas County Community College District, Ruibal's Plants of Texas, or the City of Greenville and does not imply its approval to the exclusion of other products or vendors that also may be suitable.

D.H. is the corresponding author. E-mail: derald. harp@tamuc.edu.

This is an open access article distributed under the CC BY-NC-ND license (https://creativecommons.org/ licenses/by-nc-nd/4.0/).

https://doi.org/10.21273/HORTTECH04748-20 crepe myrtle exceeded $\$ 65$ million, and there are a wide variety of cultivars, differing in size, flower color, bark color, and disease and pest resistant (Wang et al., 2016). Crepe myrtle tolerates difficult conditions across many soil types and is tolerant of low fertility, alkalinity, drought stress, heat stress; in some cultivars, it is also resistant to powdery mildew (Arnold, 2008; Cabrera, 2004; Dirr, 2009).

A cross of Red Rocket ${ }^{\circledR}$ crepe myrtle ('Whit IV') and 'Sarah's Favorite' crepe myrtle resulted in a crepe myrtle with dark foliage, 'Chocolate Mocha' (Knight and McLaurin, 2010). 'Chocolate Mocha' was used as a parent to create five more cultivars of dark-foliaged crepe myrtle with different flower colors (Pounders et al., 2013). These new cultivars have black-purple foliage that is darker than 'Chocolate Mocha' and more resistant to fading in summer sun, along with a range of flower colors including red, white, and pink. Cultivars include Ebony Embers, Ebony Fire, Ebony Flame, Ebony Glow, and Ebony and Ivory, and they are sold commercially under the Black Diamond $^{\circledR}(\mathrm{BD})$ brand under the names BD Blush (Ebony Glow), BD Pure White (Ebony and Ivory), BD Crimson Red (Ebony Fire), BD Best Red (Ebony Flame), and BD Red Hot (Ebony Embers) (Pounders et al., 2013). Each crepe myrtle in the series exhibits the dark foliage and has a similar mature size, but the cultivars vary in flower color and growth habit.

New ornamental plants are always welcome, but landscapers and homeowners face mounting challenges of decreased water availability, contamination of surface and groundwater from fertilizer runoff, and the impact of pesticides on our environment (Zlesak et al., 2015). Of these, limited irrigation water is especially important in Texas, with a potential water shortage of 5.6 million acre- $\mathrm{ft}$ per year in 2030 and irrigation water needs above 3.5 million acre-ft per year (Texas Water Development Board, 2017). The use of pesticides is decreasing as customers seek insect and disease control methods with minimal environmental impact (Harp et al., 2009; Zlesak et al., 2015). For north-central Texas, crepe myrtle is an important landscape species because it continues to provide color and landscape value when drought stress is at its most severe (JulyAugust) (Cabrera, 2004; Chretien and Harp, 2017).

\begin{tabular}{llll}
\hline $\begin{array}{l}\text { Units } \\
\begin{array}{l}\text { To convert U.S. to SI, } \\
\text { multiply by }\end{array}\end{array}$ & U.S. unit & SI unit & $\begin{array}{l}\text { To convert SI to U.S., } \\
\text { multiply by }\end{array}$ \\
\hline 1233.4819 & acre-ft & $\mathrm{m}^{3}$ & 0.0008 \\
0.3048 & ft & $\mathrm{m}$ & 3.2808 \\
3.7854 & gal & $\mathrm{L}$ & 0.2642 \\
2.54 & inch(es) & $\mathrm{cm}$ & 0.3937 \\
25.4 & inch $(\mathrm{es})$ & $\mathrm{mm}$ & 0.0394 \\
1.6093 & mile $(\mathrm{s})$ & $\mathrm{km}$ & 0.6214 \\
1 & $\mu \mathrm{mho} / \mathrm{cm}$ & $\mu S \cdot \mathrm{cm}^{-1}$ & 1 \\
1.6093 & $\mathrm{mph}$ & $\mathrm{km} \cdot \mathrm{h}^{-1}$ & 0.6214 \\
1 & $\mathrm{ppm}$ & $\mathrm{mg} \cdot \mathrm{L}^{-1}$ & 1 \\
$\left({ }^{\circ} \mathrm{F}-32\right) \div 1.8$ & ${ }^{\circ} \mathrm{F}$ & ${ }^{\circ} \mathrm{C}$ & $\left({ }^{\circ} \mathrm{C} \times 1.8\right)+32$ \\
& & &
\end{tabular}


This study was conducted to evaluate the landscape performance of Ebony crepe myrtle cultivars in north-central Texas (U.S. Department of Agriculture Plant Hardiness Zone 8) under low-input conditions.

\section{Materials and methods}

The study was conducted at three locations in Hunt County, TX, within a 15 -mile radius with similar environmental conditions but different soil characteristics. The first site, Texas A\&M University-Commerce Plant Science Center, Commerce, TX [PSC (lat. $33.196667^{\circ} \mathrm{N}$, long. $\left.\left.95.924722^{\circ} \mathrm{W}\right)\right]$ is 2 miles south of campus on Texas State Highway 24 and has a Crockett loam soil with $\mathrm{pH}$ 6.7 and low permeability $\left(<\mathrm{l} \mathrm{cm} \cdot \mathrm{h}^{-1}\right)$. Crockett has a fine, sandy loam A horizon 0 to 8 inches deep, with heavy clay below. Site two was the Texas A\&M University-Commerce Twin Oaks Blueberry Farm, Campbell, TX [BBF (lat. $33.184444^{\circ} \mathrm{N}$, long. $\left.\left.95.93^{\circ} \mathrm{W}\right)\right]$ located $\approx 1$ mile south of PSC, and has Axtell loam, Lufkin-Rader Complex, and Rader fine sandy loam soils. All soils at $\mathrm{BBF}$ are acidic, fine sandy loams with $\mathrm{pH} 5.5$ and high permeability $(>5$ $\left.\mathrm{cm} \cdot \mathrm{h}^{-1}\right)$. Site three was the Greenville Sports Park, Greenville, TX [GSP (lat. $33.098333^{\circ} \mathrm{N}$, long. $96.121389^{\circ} \mathrm{W}$ )] roughly 15 miles southwest of PSC, with Leson clay and Ferris-Heiden Complex soils. GSP soils are moderately alkaline clays $(\mathrm{pH} 8.2)$ with low permeability $\left(<\mathrm{l} \mathrm{cm} \cdot \mathrm{h}^{-1}\right)$.

During this study, soils were modified only during preplant bed preparation. Beds were tilled to a depth of 12 inches, covered with 3 inches of compost, and tilled again. Drip irrigation lines (XF; Rain Bird Corp., Azusa, CA) were installed in the middle of each bed with lines parallel to each other, placed 18 inches apart and emitters every 18 inches $(0.6 \mathrm{gal} / \mathrm{h})$ at PSC and GSP. At $\mathrm{BBF}$, drip irrigation lines were place 18 inches apart with emitters every 12 inches $(0.9 \mathrm{gal} / \mathrm{h})$, spaced to meet drip irrigation design standards on sandy soils.

After planting, all beds were covered with 3 inches of shredded cedar mulch, and additional mulch was added annually to maintain the 3 -inch depth. No fertilizer or pesticides were applied to the soil except glyphosate for weed control. Irrigation was applied twice weekly, timed to provide irrigation equivalent to 2 inches of precipitation per week, during year 1 to ensure establishment and asneeded in year 2 to maintain plant quality.

Plant materials. Six crepe myrtle cultivars were selected. Ebony crepe myrtle cultivars were donated (J. Berry Nursery, Grand Saline, TX) and Centennial Spirit was purchased (Tawakoni Plant Farm, Wills Point, TX). All plants were purchased in \#2 (1.5 gal) containers and were about the same size at planting (Table 1 ). Plants were stored and watered regularly at PSC until planting (up to 4 weeks). The Ebony crepe myrtle cultivars were Ebony Embers, Ebony Fire, Ebony Flame, Ebony Glow, and Ebony and Ivory. The Ebony cultivars are medium sized [up to $13 \mathrm{ft}$ (Pounders et al., 2013)] but with unknown resistance to disease and pests.

'Centennial Spirit' is a redflowered crepe myrtle with a mature height between 14 and $16 \mathrm{ft}$ that is well adapted to north-central Texas, being chosen as one of the best medium-sized (10 to $20 \mathrm{ft}$ ) crepe myrtle cultivars (Crape Myrtle Trails of McKinney, 2020). 'Centennial Spirit' has a reported mature size similar to the Ebony cultivars (Pounders et al., 2013), good drought tolerance, good resistance to powdery mildew [Erysiphye lagerstroemiae (Wade and Woodward, 2009; Whitcomb, 1985)], and good resistance to crepe myrtle aphid [Tinocallis kabawaluokalani (Mizell and Knox, 1993)] but is moderately susceptible to flea beetles [Altica sp.
(Pettis et al., 2004)], so it was used as an experimental standard.

Cultivars were assigned randomly to one of six locations within each bed on $10-\mathrm{ft}$ centers. Four beds were built at each location with each cultivar represented once in each bed, and a total of 24 plants per location. All trees were planted in Mar. 2014 and allowed to establish for 2 years.

Beginning in 2016, plants were visually assessed once monthly during the growing season (April to October). Plants were scored using a 0 to 10 scale on foliage cover, flower coverage, drought stress, disease incidence, and pest infestation using a scale modified from Harp et al. (2009). An overall landscape performance score was generated by averaging across all categories. Regardless of measure, a score of 0 indicated a dead plant. For foliage, a score of 10 was indicative of $100 \%$ foliage cover, with the rating decreasing by 1 for each $10 \%$ drop in foliage cover. For bloom coverage scores, a score of 10 represented open blooms on $100 \%$ of primary stems, decreasing by 1 for each $10 \%$ drop in primary stems with blooms (Table 2 ).

Leaf and stem wilting, browning and necrosis of leaf margins, and yellowing of foliage were used as indicators of plant drought stress (Harp et al., 2015, 2019; Pinior et al., 2005). Plant scores represented a visual estimate of the percentage of the plant with drought symptoms, with a score of 10 indicative of $100 \%$ of the plant being free of drought stress symptoms. Similarly, disease incidence and pest infestation were scored by deducting 1 point for each $10 \%$ of the

Table 1. Average height of crepe myrtle cultivars planted in low-input gardens at three north-central Texas locations at study initiation (2014) and study end (2017).

\begin{tabular}{|c|c|c|c|c|c|}
\hline \multirow[b]{2}{*}{ Cultivar } & \multicolumn{4}{|c|}{2017 Avg ht (inches) ${ }^{z}$} & \multirow{2}{*}{$\begin{array}{l}2014 \text { Avg ht } \\
\text { (inches) }\end{array}$} \\
\hline & Mean & BBF & GSP & PSC & \\
\hline Centennial Spirit & $76.4 \mathrm{a}^{\mathrm{y}}$ & $66.8 \mathrm{a}$ & $60.5 \mathrm{a}$ & $102.0 \mathrm{a}$ & $26.3 \mathrm{~b}$ \\
\hline Ebony Flame & $56.7 \mathrm{~b}$ & $40.8 \mathrm{ab}$ & $50.7 \mathrm{ab}$ & $77.3 \mathrm{~b}$ & $27.8 \mathrm{ab}$ \\
\hline Ebony Glow & $50.6 \mathrm{~b}$ & $42.7 \mathrm{ab}$ & $37.3 \mathrm{~b}$ & $70.0 \mathrm{bc}$ & $30.3 \mathrm{a}$ \\
\hline Ebony Fire & $49.4 \mathrm{~b}$ & $44.0 \mathrm{ab}$ & $47.7 \mathrm{ab}$ & $54.8 \mathrm{~d}$ & $26.3 \mathrm{~b}$ \\
\hline Ebony Embers & $46.5 \mathrm{~b}$ & $35.5 \mathrm{~b}$ & $38.5 \mathrm{~b}$ & $65.5 \mathrm{c}$ & $28.0 \mathrm{ab}$ \\
\hline Ebony and Ivory & $46.2 \mathrm{~b}$ & $45.0 \mathrm{ab}$ & $49.8 \mathrm{ab}$ & $43.0 \mathrm{e}$ & $25.6 \mathrm{~b}$ \\
\hline
\end{tabular}

${ }^{\mathrm{z}}$ Mean $=$ overall mean comparing across all locations; $\mathrm{BBF}=$ Texas A\&M University-Commerce Twin Oaks Blueberry Farm, Campbell, TX; GSP = Greenville Sports Park, Greenville, TX; PSC = Texas A\&M UniversityCommerce Plant Science Center, Commerce, TX; 1 inch $=2.54 \mathrm{~cm}$.

${ }^{y}$ Statistical analysis conducted using the GLIMMIX procedure of SAS (version 9.4; SAS Institute, Cary, NC) using a normal distribution and identity function. Means were separated using Fisher's least significant difference with $\alpha=0.05$. Means within columns followed by the same letter are not significantly different. 


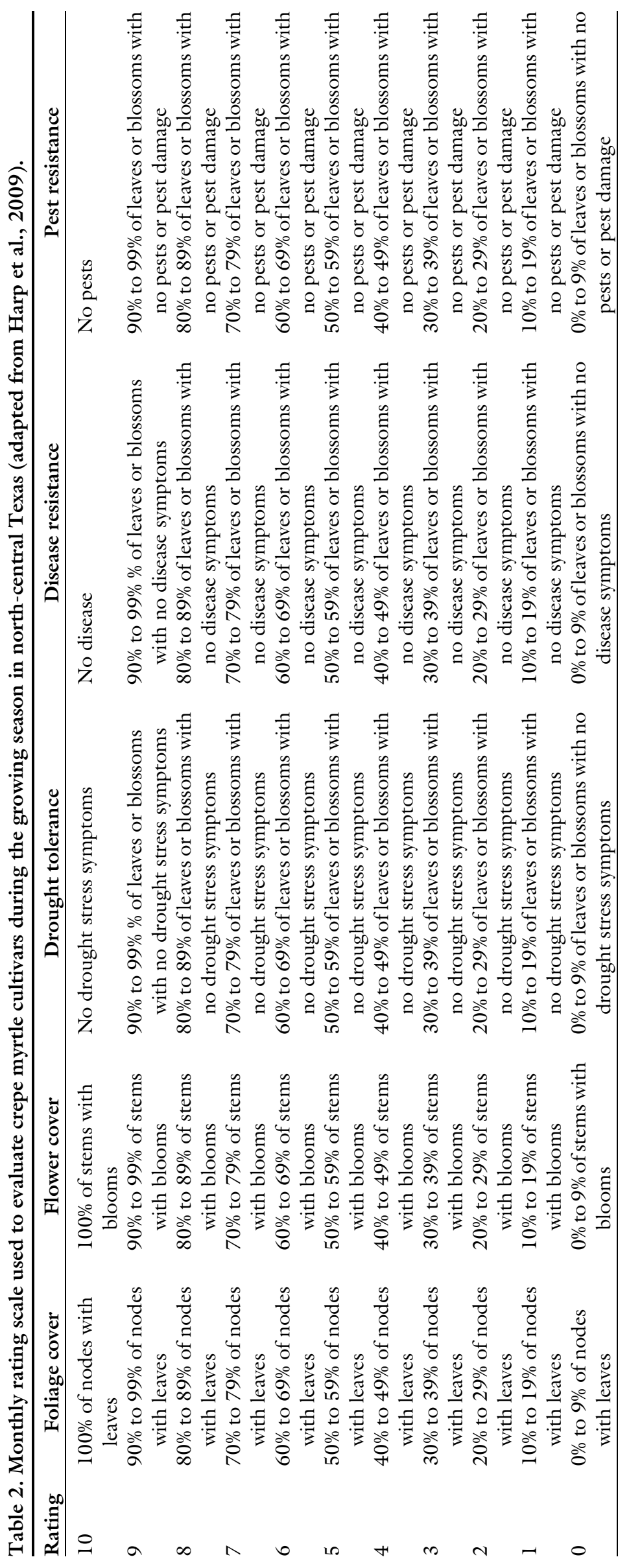

plant with disease or visible pests. Diseases identified were powdery mildew, leaf spot (Cercospora lythracearum), and sooty mold (Capnodium sp.). Pests included the crepe myrtle aphid, flea beetles, and crepe myrtle bark scale (Acanthococcus lagerstroemiae).

Plants were measured for leaf greenness (SPAD 502; Minolta Camera Co., Ramsey, NJ) once monthly, and leaf temperature was taken in August using a portable photosynthesis system with a leaf temperature thermocouple (LI-6400XT; LI-COR BioSciences, Lincoln, NE). Plant height and width were taken at the end of each growing season. Height was taken to the tallest single stem, and width was measured twice, with the second perpendicular to the first.

The UNIVARIATE procedure of SAS (version 9.4; SAS Institute, Cary, NC) was used to perform a normality test on the data collected and determine data distribution. Height and width satisfied KolmogorovSmirnov $(P>0.05)$ normality tests, whereas data for no other variables were normally distributed. All data were analyzed using the GLIMMIX procedure of SAS (version 9.4) with a Laplace approximation and a Newton-Raphson optimization. A normal distribution and identity link function was used for height and width, and a negative binary distribution and a $\log$ link function was used for all score data (Stroup, 2015). Covariance structure was selected using the Akaike's information criterion score. Means separation was conducted using Shaffer's simulated method $(\alpha=$ 0.05 ).

Pooled analyses were run using location and year as blocking factors, and separate analyses were run by location and year using cultivar and location as independent variables. Although location differences were identified, cultivar $\times$ location and cultivar $x$ year interaction was not significant $(P>0.05)$, so data were pooled, in most instances, for presentation purposes.

\section{Results and discussion}

ENVIRONMENTAL AND SOIL CONDITIONs. As expected, soil chemical properties and plant nutrient levels differed between the three locations (Table 3 ). Soil $\mathrm{pH}$ was 6.1 at BBF, 7.7 at PSC, and 8.21 at GSP. All 


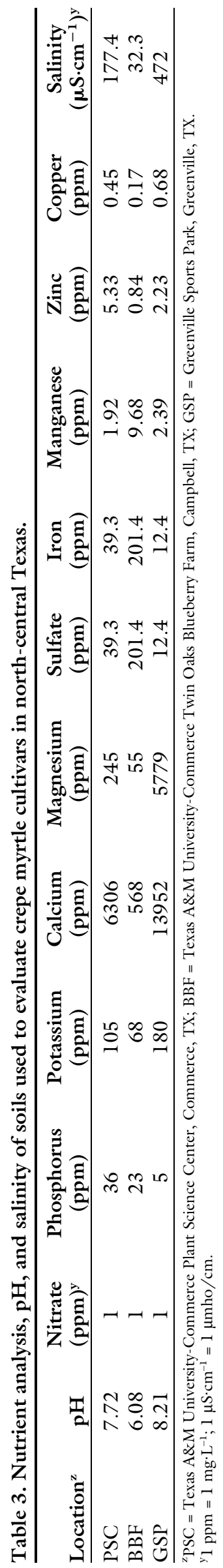

locations were low in nitrate but varied with other nutrients. GSP had very high levels of potassium (K), calcium $(\mathrm{Ca})$, and magnesium $(\mathrm{Mg})$, but low levels of available phosphorus (P). PSC also had high levels of $\mathrm{Ca}$ and $\mathrm{Mg}$, but moderate levels of $\mathrm{P}$ and low K. BBF had moderate levels of $\mathrm{Ca}$ and $\mathrm{P}$, but low levels of $\mathrm{K}$ and $\mathrm{Mg}$. Iron levels were highest at $\mathrm{BBF}$ (201.4 ppm), with considerably lower levels at PSC (39.3 ppm) and GSP (12.4 ppm). Although locations differed considerably in soil analyses, no nutrient deficiency symptoms were noted on any plants at any location. Further, SPAD meter readings were all high, ranging from 64.7 to 70.8 , readings consistent with fertilized leaves in crepe myrtle (DemotesMainard et al., 2008), and these readings were consistent across all cultivars and all locations.

As sites were separated by less than 15 miles, all locations were under the same regional weather, but microclimates varied due to the openness of the site and absence of structures and large vegetation. For example, winds were considerably higher at GSP. Although not regularly measured as part of the study, wind speeds were collected on 12 occasions using a handheld anemometer (1000; Kestrel Instrument, Boothwyn, PA). Wind collection was made at times with high winds $(>10$ $\mathrm{mph})$, moderate winds (5-10 $\mathrm{mph}$ ), and low winds $(<5 \mathrm{mph})$, as recorded at Majors Field, Greenville, TX. All wind speeds were collected in midafternoon between 3:15 and 4:30 PM and within a 60 -min time period. During periods of high winds, winds at GSP averaged $15.4 \mathrm{mph}$, whereas BBF and PSC averaged 6.3 and 6.1 $\mathrm{mph}$, respectively. On days with very low winds $(<5.0 \mathrm{mph})$, GSP averaged $3.8 \mathrm{mph}$, while BBF and PSC averaged 1.5 and $1.8 \mathrm{mph}$. On average, winds at GSP were $5.5 \mathrm{mph}$ higher than BBF and PSC.

Leaf temperatures were generally slightly higher than air temperature, with leaves 0.4 to $0.6^{\circ} \mathrm{C}$ warmer than ambient air temperatures, but no differences were found among cultivars in leaf temperature, with average temperatures ranging from 31.1 to $32.2{ }^{\circ} \mathrm{C}$. The blackbody radiation absorption concept predicts that the darker colored leaves should absorb more electromagnetic radiation, and, to stay in equilibrium, must emit radiation, typically as sensible heat (Mutlaq, 2020). For example, crepe myrtle leaves with sooty mold are typically 1.5 to $2.0{ }^{\circ} \mathrm{C}$ warmer than sooty mold-free leaves (Kim et al., 2016). However, dark leaves are darker because of higher concentrations of anthocyanins or carotenoids that capture and dissipate incoming radiation while also allowing chlorophyll to form at luxuriant levels (Borek et al., 2016; Hatier and Gould, 2007). Light to the adaxial side of the leaf is reduced by $\approx 5 \%$, but only in green wavelengths and with no effect on red or blue light levels. Therefore, darker leaves actually provide a physiological advantage over green leaves, and the consumption and dissipation of radiative energy leads to leaf temperatures similar to those of green-leaved cultivars (Hatier et al., 2013).

Three plants died during the trial, but with no more than one plant per block. 'Ebony Glow' was lost at $\mathrm{BBF}$ for unknown reasons, and one 'Ebony Flame' and one 'Ebony Fire' were lost at GSP due to mowing accidents. These were not replaced. At PSC, an 'Ebony and Ivory' was lost shortly after planting and replaced with an 'Ebony Fire'. All plant losses occurred during year 1 .

LANDSCAPE PERFORMANCE. In overall landscape performance, 'Centennial Spirit' outperformed all other cultivars tested (Table 4). 'Centennial Spirit' had an overall landscape performance average of 7.5 , followed by the cultivars Ebony Embers (6.2) and Ebony Flame (6.2), with Ebony Fire (6.1), Ebony Glow (5.7), and Ebony and Ivory (5.6) (Table 4). Across locations, overall landscape performance was best at PSC (6.1), followed by GSP (5.5), then BBF (5.2). Although differences were found between Ebony cultivars, Centennial Spirit had landscape performance scores nearly a point higher than the Ebony cultivars at each location (Table 4).

'Centennial Spirit' had higher foliage (7.5), flower (3.0), and disease (9.5) scores than the Ebony cultivars (Table 5). Flower scores were low for all cultivars tested. Crepe myrtle are summer blooming plants, and the highest bloom scores were recorded in July (4.0), August (3.6), and September (3.6). Virtually no blooms 
were noted in May (0.007), and few blooms in June (0.1). When lowflowering months are omitted, scores increase for all cultivars, and Centennial Spirit (5.4) still exceeds all Ebony cultivars (Ebony Fire 3.9, Ebony and Ivory 3.7, Ebony Embers 3.6, Ebony Flame 3.2, and Ebony Glow 2.7).

Unfortunately, low flower numbers for Ebony cultivars is consistent with other studies. In a flower count of crepe myrtle cultivars during peak bloom, Natchez and Tuscarora trees averaged 401 and 389 open blooms (defined as flowers with exserted anthers) per tree, whereas Ebony Fire averaged only 132 (T.N. Bahzaw and D.A. Harp, unpublished data). Further, 'Natchez' maintained an average of 100 or more open blooms for 5 weeks, whereas 'Ebony Fire' had over 100 open blooms for only 2 weeks.
Drought tolerance was excellent for all cultivars across all locations (Table 5). Although the high winds and corresponding water deficits limited plant growth at GSP, and plants on the sandy loam soils at BBF has less available water, no drought stress symptoms, such as wilting, leaf browning, marginal browning or necrosis, or deficiency symptoms were observed at any location.

'Centennial Spirit' was developed for resistance to powdery mildew (Whitcomb, 1985), so it comes as no surprise it has the lowest overall disease incidence [9.5 (Table 5)]. All Ebony cultivars were heavily infected with powdery mildew, with considerable disease present through June (Table 5). Disease incidence subsided in June and July before reoccurring in August, likely sooty mold associated with the presence of crepe myrtle aphid and crepe myrtle bark scale.

Table 4. Average monthly ratings for landscape performance for crepe myrtle cultivars evaluated during the 2016 and 2017 growing seasons (April to October) at three locations under low-input conditions in north-central Texas, ranked in order of overall landscape performance score.

\begin{tabular}{lcccc}
\hline & $\begin{array}{c}\text { Overall landscape } \\
\text { performance }\end{array}$ & $\begin{array}{c}\text { Twin Oaks } \\
\text { Blueberry Farm }\end{array}$ & $\begin{array}{c}\text { Greenville } \\
\text { Sports Park }^{\mathbf{z}}{ }^{\mathrm{y}}\end{array}$ & $\begin{array}{c}\text { Plant Science } \\
\text { Center }^{\mathrm{z}}\end{array}$ \\
\cline { 2 - 5 } Cultivar & \multicolumn{2}{c}{ Avg landscape performance (0-10 scale) } & \\
\hline Centennial Spirit & $7.5 \mathrm{a}^{\mathrm{x}}$ & $7.5 \mathrm{a}$ & $7.1 \mathrm{a}$ & $7.9 \mathrm{a}$ \\
Ebony Embers & $6.2 \mathrm{~b}$ & $5.4 \mathrm{~b}$ & $6.4 \mathrm{a}$ & $6.8 \mathrm{a}$ \\
Ebony Flame & $6.2 \mathrm{~b}$ & $6.3 \mathrm{ab}$ & $5.6 \mathrm{a}$ & $6.5 \mathrm{ab}$ \\
Ebony Fire & $6.1 \mathrm{~b}$ & $5.7 \mathrm{~b}$ & $5.8 \mathrm{a}$ & $7.0 \mathrm{a}$ \\
Ebony Glow & $5.7 \mathrm{~b}$ & $5.5 \mathrm{~b}$ & $5.4 \mathrm{a}$ & $6.2 \mathrm{ab}$ \\
Ebony and Ivory & $5.6 \mathrm{~b}$ & $5.6 \mathrm{~b}$ & $6.3 \mathrm{a}$ & $4.9 \mathrm{~b}$ \\
\hline
\end{tabular}

${ }^{\mathrm{z}}$ Texas A\&M University-Commerce Twin Oaks Blueberry Farm, Campbell, TX; Greenville Sports Park, Greenville, TX; Texas A\&M University-Commerce Plant Science Center, Commerce, TX.

${ }^{\mathrm{y}}$ Landscape performance was determined averaging scores for foliage, flower, drought stress, disease, and pests. Overall landscape performance is averaged across locations and years. Scores are based on criteria described in Table 2.

${ }^{\mathrm{x}}$ Statistical analysis conducted using the GLIMMIX procedure (version 9.4; SAS Institute, Cary, NC), using a Newton-Raphson optimization, a negative binomial distribution, and a log link. Means were separated using the Shaffer-simulated method with $\alpha=0.05$. Means within columns followed by the same letter are not significantly different. Cultivar $\times$ year interaction was not significant, so data are pooled across years for presentation purposes.
All of the cultivars tested had good pest resistance, with flea beetles and crepe myrtle bark scale damage being the most common (Table 5). Flea beetle damage occurred in all locations, although damage was not severe. Crepe myrtle bark scale was more prevalent at PSC and GSP, and, in these locations, crepe myrtle bark scale was found on all cultivars equally.

Plant size. At the end of year 4 and across all locations, 'Centennial Spirit' grew more than any other cultivar tested, reaching an average of 76.4 inches in height, an increase of over 50 inches (Table 1). Growth in the Ebony cultivars was considerably less, with average increases in height ranging from +28.9 inches in Ebony Flame (+28.9 inches) to 20.6 inches in 'Ebony and Ivory' (Table 1 ).

'Centennial Spirit' also had the greatest increase in width, reaching an average width of 40.9 inches, compared with 36.6, 32.0, and 24.2 inches for, 'Ebony Flame', 'Ebony Embers', and 'Ebony Glow', respectively. 'Ebony and Ivory' only increased in width by 3.2 inches during the study period.

Differences in growth could be related to genetic differences among the cultivars rather than better performance by Centennial Spirit. When initially released, 'Centennial Spirit' was expected to have a mature size of 7 to $10 \mathrm{ft}$, whereas the Ebony cultivars were expected to mature at 7 to $12 \mathrm{ft}$ (Pounders et al., 2013; Whitcomb, 1985). Today, we know 'Centennial Spirit' has a mature size of 14 to $16 \mathrm{ft}$ (Crape Myrtle Trails of McKinney, 2020), and Ebony cultivars will have a maximum height between 10 and $12 \mathrm{ft}$. Ebony cultivars

Table 5. Average monthly ratings for landscape performance, foliage, flower, drought, disease, and pests for crepe myrtle cultivars evaluated in 2016 and 2017 under low-input conditions at three locations in north-central Texas, ranked in order of greatest landscape performance score.

\begin{tabular}{|c|c|c|c|c|c|c|}
\hline \multirow[b]{2}{*}{ Cultivar } & Landscape performance & Foliage cover & Flower cover & Drought tolerance & Disease resistance & Pest resistance \\
\hline & \multicolumn{6}{|c|}{ Avg rating $(0-10 \text { scale })^{\mathrm{z}}$} \\
\hline Centennial Spirit & $7.5 \mathrm{a}^{\mathrm{y}}$ & $7.5 \mathrm{a}$ & $3.0 \mathrm{a}$ & $10.0 \mathrm{a}$ & $9.5 \mathrm{a}$ & $9.3 \mathrm{a}$ \\
\hline Ebony Flame & $6.2 \mathrm{~b}$ & $6.1 \mathrm{~b}$ & $1.8 \mathrm{~b}$ & $10.0 \mathrm{a}$ & $7.4 \mathrm{~b}$ & $8.7 \mathrm{a}$ \\
\hline Ebony Fire & $6.1 \mathrm{~b}$ & $6.2 \mathrm{~b}$ & $2.2 \mathrm{~b}$ & $10.0 \mathrm{a}$ & $7.6 \mathrm{~b}$ & $9.0 \mathrm{a}$ \\
\hline Ebony Glow & $5.7 \mathrm{~b}$ & $5.7 \mathrm{~b}$ & $2.1 \mathrm{~b}$ & $10.0 \mathrm{a}$ & $7.5 \mathrm{~b}$ & $8.2 \mathrm{a}$ \\
\hline
\end{tabular}

\footnotetext{
${ }^{\mathrm{z}}$ Landscape performance was determined averaging scores for foliage, flower, drought, disease, and pests. Scores based on criteria described in Table 2.
}

${ }^{y}$ Statistical analysis conducted using the GLIMMIX procedure (version 9.4; SAS Institute, Cary, NC). Means were separated using the Shaffer-simulated method with $\alpha=0.05$. Means within columns followed by the same letter are not significantly different. Neither cultivar $\times$ location nor cultivar $\times$ year interaction were significant, so data are pooled for presentation purposes. 
Table 6. Average monthly disease ratings for crepe myrtle cultivars evaluated in 2016 and 2017 under low-input conditions in north-central Texas.

\begin{tabular}{lccccc}
\hline \multirow{2}{*}{ Cultivar } & May & June & July & August & September \\
\cline { 2 - 6 } & \multicolumn{5}{c}{ Avg disease rating $(\mathbf{0}-\mathbf{1 0} \text { scale })^{\mathrm{z}}$} \\
\hline Centennial Spirit & $9.9 \mathrm{a}^{\mathrm{y}}$ & $9.8 \mathrm{a}$ & $9.7 \mathrm{a}$ & $9.0 \mathrm{a}$ & $8.9 \mathrm{a}$ \\
Ebony Flame & $6.2 \mathrm{~b}$ & $8.3 \mathrm{~b}$ & $8.6 \mathrm{ab}$ & $6.4 \mathrm{~b}$ & $8.6 \mathrm{ab}$ \\
Ebony Glow & $7.6 \mathrm{~b}$ & $6.9 \mathrm{~b}$ & $7.7 \mathrm{~b}$ & $5.9 \mathrm{~b}$ & $7.2 \mathrm{c}$ \\
Ebony Fire & $7.1 \mathrm{~b}$ & $8.2 \mathrm{~b}$ & $8.3 \mathrm{~b}$ & $7.3 \mathrm{ab}$ & $7.5 \mathrm{bc}$ \\
Ebony and Ivory & $6.7 \mathrm{~b}$ & $7.5 \mathrm{~b}$ & $8.6 \mathrm{ab}$ & $7.4 \mathrm{ab}$ & $7.6 \mathrm{bc}$ \\
Ebony Embers & $7.6 \mathrm{~b}$ & $8.1 \mathrm{~b}$ & $8.5 \mathrm{ab}$ & $6.9 \mathrm{~b}$ & $8.0 \mathrm{abc}$
\end{tabular}

${ }^{\mathrm{z}} \mathrm{S}$ cores based on criteria described in Table 2 .

${ }^{y}$ Statistical analysis conducted using the GLIMMIX procedure (version 9.4; SAS Institute, Cary, NC). Means were separated using the Shaffer-simulated method with $\alpha=0.05$. Means within columns followed by the same letter are not significantly different. Neither cultivar $\times$ location nor cultivar $\times$ year interaction were significant, so data are pooled for presentation purposes.

are also reported to be slower growing than other crepe myrtle cultivars (C. Cotton, personal communication).

Crepe myrtle are considered fastgrowing trees, capable of $2 \mathrm{ft}$ of growth annually. After year 1 , where little growth occurred, 'Centennial Spirit' grew more than 75 inches over the next two growing seasons at PSC, the location with the most growth, an average of more than $3 \mathrm{ft}$ per year. This was likely exacerbated in the lowinput landscape, with soil nitrate levels at $1 \mathrm{ppm}$ (Table 2 ), compared with the $60 \mathrm{ppm}$ recommended for crepe myrtle production (Cabrera and Devereaux, 1998).

Across all cultivars, plants at PSC were taller (69.3 inches) than those at GSP (47.2 inches) and BBF (45.9 inches), and plant width was greater at PSC (34.9 inches) and GSP (31.1 inches) than BBF (24.7 inches). Plants in continuous high wind are generally smaller (Gardiner et al., 2016), and this is consistent with the growth seen at GSP. Sandy soils at BBF likely limited long-term water and nutrient availability, resulting in overall smaller plants.

Although differences did exist among study sites, cultivar rankings were consistent across all locations. 'Centennial Spirit' was the largest cultivar (both height and width) at BBF (Table 1), but similar in height to the cultivars Ebony and Ivory, Ebony Flame, and Ebony Fire at GSP and similar in height to all cultivars except Ebony Embers at BBF.

\section{Conclusions}

The dark foliage of the Ebony cultivars adds to the wide variety of colors available from crepe myrtle. Unfortunately, although their drought stress and pest tolerance was similar, the landscape performance of the Ebony crepe myrtle was not comparable to 'Centennial Spirit' when used in low-input landscapes favored by today's gardeners. These issues may disappear in an intensively managed landscape, but in low-input gardens, the Ebony cultivars grew slower than expected for crepe myrtle, had a high incidence of powdery mildew, and bloomed less than expected.

\section{Literature cited}

Arnold, M.A. 2008. Landscape plants for Texas and environs. 4th ed. Stipes Publ., Champaign, IL.

Borek, M., R. Baczek-Kwinta, and M. Rapacz. 2016. Photosynthetic activity of variegated leaves of Coleus $\times$ hybridus hort. cultivars characterized by chlorophyll fluorescence techniques. Photosynthetica 54:331-339, doi: 10.1007/s11099-0160225-7.

Cabrera, R.I. 2004. Evaluating and promoting the cosmopolitan and multipurpose Lagerstroemia. Acta Hort. 630:177184, doi: 10.17660/ActaHortic.2004. 630.21 .

Cabrera, R.I. and D.R. Devereaux. 1998. Effects of nitrogen supply on growth and nutrient status of containerized crape myrtle. J. Environ. Hort. 16:98-104.

Chretien, K. and D.A. Harp. 2017. Performance of Black Diamond ${ }^{\circledR}$ crepe myrtles (Lagerstroemia indica L.) in northeast Texas. HortScience 52:S38 (abstr.).

Crape Myrtle Trails of McKinney. 2020. Best crape myrtles by size. 18 Nov 2020 . <https://crapemyrtletrails.org/ varieties/best-crape-myrtles-by-size/>.

Demotes-Mainard, S., R. Boumaza, S. Meyer, and Z.G. Cerovic. 2008. Indicators of nitrogen status for ornamental woody plants based on optical measure- ments of leaf epidermal polyphenol and chlorophyll contents. Scientia Hort. 115:377-385, doi: 10.1016/j.scienta. 2007.10.006.

Dirr, M.A. 2009. Manual of woody landscape plants. 6th ed. Stipes Publ., Champaign, IL.

Gardiner, B., P. Berry, and B. Moulia. 2016. Review: Wind impacts on plant growth, mechanics, and damage. Plant Sci. $245: 94-118$, doi: 10.1016/j-plantsci. 2016.01.006.

Harp, D.A., D.C. Zlesak, G. Hammond, S. George, and W. Mackay. 2009. Earth$\mathrm{Kind}^{\text {TM }}$ rose trials-Identifying the world's strongest, most beautiful landscape roses. Floric. Ornam. Biotechnol. 3:166-175.

Harp, D., G. Hammond, D.C. Zlesak, G. Church, M. Chamblee, and S. George. 2019. Flowering, drought and disease tolerance, and landscape performance of landscape roses grown under low input conditions in north-central Texas. HortTechnology 29:234-240, doi: 10.21273/ HORTTECH04215-18.

Harp, D.A., K. Kay, D.C. Zlesak, and S. George. 2015. The effect of rose root size on drought stress tolerance and landscape plant performance. Tex. J. Agr. Nat. Resour. 28:82-88.

Hatier, J.H.B., M.J. Clearwater, and K.S. Gould. 2013. The functional significance of black-pigmented leaves: Photosynthesis, phytoprotection, and productivity in Ophiopogon planiscapus 'Nigrescens'. PLoS One 8:e67850, doi: 10.1371/ journal.pone.0067850.

Hatier, J.H.B. and K.S. Gould. 2007. Black coloration in leaves of Ophiopogon planiscapus 'Nigrescens'. Leaf optics, chromaticity, and internal light gradients. Func. Plant Biol. 34:130-138, doi: 10.1071/FP06220.

Kim, J., S. Kweon, J. Park, H. Lee, and K.W. Kim. 2016. Digital infrared thermal imaging of crape myrtle leaves infested with sooty mold. Plant Pathol. J. 32:563569, doi: 10.5423/PPJ.NT.04.2016. 0112 .

Knight, P.R. and W. McLaurin. 2010. Crapemyrtle plant named 'Chocolate Mocha'. U.S. Plant Patent USPP2 1540P2. Filed 29 May 2009. Issued 30 Nov. 2020.

Mizell, R.F., III., and G.W. Knox. 1993. Susceptibility of crape myrtle, Lagerstroemia indica L., to the crapemyrtle aphid (Homoptera: Aphididae) in north Florida. J. Entomol. Sci. 28:1-7.

Mutlaq, J. 2020. The AstroInfo Project: Blackbody radiation. 29 Sept 2020. <https://docs.kde.org/trunk5/en/ extragear-edu/kstars/ai-blackbody.html . 
Pettis, G.V., D.W. Boyd, Jr., K. Braman, and C. Pounders. 2004. Potential resistance of crape myrtle cultivars to flea beetle (Coleoptera: Chrysomelidae) and japanese beetle (Coleoptera: Scarabaeidae) damage. J. Econ. Entomol. 97:981-992, doi: 10.1603/022-0493(2004)097[0981: procmc $] 2.0 \mathrm{co} ; 2$.

Pinior, A., G. Grunewaldt-Stöcker, H. vol Alten, and R.J. Strasser. 2005. Mycorrhizal impact on drought stress tolerance of rose plants probed by chlorophyll $a$ fluorescence, proline content and visual scoring. Mycorrhiza 15:596-605, doi: 10.1007/s00572-005-0001-1.

Pounders, C., B. Scheffler, and T. Rinehart. 2013. 'Ebony Embers', 'Ebony Fire',
'Ebony Flame', 'Ebony Glow', and 'Ebony and Ivory' dark-leaf crapemyrtles. HortScience 48:1568-1570, doi: 10.21273/ HORTSCI.48.12.1568.

Stroup, W.W. 2015. Rethinking the analysis of non-normal data in plant and soil science. Agron. J. 107:811-827, doi: 10.2134/agronj2013.0342.

Texas Water Development Board. 2017. Water supply needs, p. 76-85. In: 2017 State Water Plan. Texas Water Dev. Board, Austin, TX.

Wade, G.L. and J.W. Woodward. 2009. Crape myrtle culture. Univ. Georgia Coop. Ext. Serv. Circ. 944.
Wang, Z., Y. Chen, M. Gu, E. Vafaie, M. Merchant, and R. Diaz. 2016. Crapemyrtle bark scale: A new threat for crapemyrtles, a popular landscape plant in the U.S. MDPI Insects 7:78, doi: 10.3390/ insects7040078.

Whitcomb, C.E. 1985. 'Centennial Spirit' crapemyrtle. HortScience 20:1144-1145.

Zlesak, D.C., D.A. Harp, K. Zuzek, J.J. Sloan, A. Owings, and S.W. George. 2015. Earth-Kind ${ }^{\circledR}$ rose trialing: An international model for the identification of regionally adapted landscape roses. Acta Hort. 1064:123-129, doi: 10.17660/ ActaHortic.2015.1064.15. 